\title{
Response of Cucurbit Species to Rotylenchulus reniformis*
}

\author{
Gustavo R. C. Torres ${ }^{1}$, Elvira M. R. Pedrosa ${ }^{2}$, Kércya M. S. Siqueira ${ }^{1}$ \& Romero M. Moura ${ }^{2}$ \\ Departamento de Agronomia, UFRPE, Rua D. Manoel de Medeiros, s/n, Dois Irmãos, CEP 52171-900, Recife-PE, \\ fax: (081) 3302-1205, e-mail: epedrosa@ufrpe.br
}

(Accepted for publication in 09/08/2004)

Corresponding author: Elvira M. R. Pedrosa

TORRES, G.R.C., PEDROSA, E.M.R, SIQUEIRA, K.M.S. \& MOURA, R.M. Response of cucurbit species to Rotylenchulus reniformis. Fitopatologia Brasileira 30:85-87. 2005.

\begin{abstract}
The state of Rio Grande do Norte is the major melon (Cucumis melo) producer in Brazil and the reniform nematode Rotylenchulus reniformis has become increasingly important due to damages to that crop and the lack of resistant cultivars and effective control measures. Under these circumstances, eight cucurbit genotypes were screened for resistance or tolerance to a population of $R$. reniformis in naturally infested field soil, under greenhouse conditions. A high reduction in shoot mass was found in all infected genotypes. Watermelon (Citrullus lanatus) cv. Sugar Baby showed the lowest rate of nematode reproduction.

Additional keywords: reniform nematode, resistance, tolerance, Cucumis spp.

\section{RESUMO}

Resposta de genótipos de cucurbitáceas a Rotylenchulus reniformis

O estado do Rio Grande do Norte é o principal produtor de melão (Cucumis melo) do Brasil, tendo o nematóide Rotylenchulus reniformis relevante importância devido ao potencial de dano à cultura e inexistência de cultivares resistentes e medidas de controle efetivas. Sob estas circunstâncias, oito espécies de cucurbitáceas foram avaliadas quanto a resistência e tolerância a uma população nativa de $R$. reniformis em solo naturalmente infestado, em casa de vegetação. Ocorreu alta redução em biomassa fresca da parte aérea em todos os genótipos estudados. A melancia (Citrullus lanatus) cv. Sugar Baby apresentou a mais baixa taxa de reprodução do nematóide.
\end{abstract}

Palavras-chave adicionais: nematoide reniforme, resistência, tolerância, Cucumis spp.

From 1996 to 2001, the state of Rio Grande do Norte yielded $57 \%$ of the Brazilian melon (Cucumis melo L.) production (IBGE, 2003). In Mossoró and Açu municipalities, high yield losses have recently been associated with high population densities of the reniform nematode (Rotylenchulus reniformis Linford \& Oliveira) (Moura et al., 2002). A lack of resistant genotypes for practical and effective nematode control measures has limited profitable melon yields in these areas. The objective of this research was to evaluate, in the greenhouse using naturally infested soil, the reaction of cucurbit genotypes (seven local and economically valuable crops along with an ordinary weed) to the reniform nematode. This information is needed for management assistance in crop rotation. The genotypes evaluated were the melons $C$. melo var. cantalupensis Naud. and C. melo var. inodorus Naud., cucumber (Cucumis sativus L.) cv. Marketer, gherkin (Cucumis anguria L.) cv. Maxixe do Norte, watermelon (Citrullus lanatus Thunb.) cv. Sugar Baby, summer squash (Cucurbita pepo L.) var. melopepo cv. Abobrinha Brasileira, squash (Cucurbita moschata Duch. ex Poiret) cv. Baiana Tropical and the weed Mormodica charantia L. The experiment was

\footnotetext{
*Part of the D. S. thesis of the first author. Universidade Federal Rural de Pernambuco (2005)

${ }^{1}$ CAPES Fellowship

${ }^{2} \mathrm{CNPq}$ Fellowship
}

composed of 16 treatments (eight genotypes in both naturally infested soil and control) and four replications arranged in a completely randomized design. Each replication corresponded to a plant grown in a $500-\mathrm{cm}^{3}$ pot, filled with naturally infested soil from Baraúna municipality melon fields. Nematode initial population (Pi) was assessed by centrifugal flotation procedure according to Jenkins (1964), and determined to be around five juveniles and immature females forms $/ 500 \mathrm{~cm}^{3}$ of soil. Evaluations were carried out 70 days after seeds were sown, based on the relative biomass (RB) of each germplasm. The RB was the shoot fresh mass (SFM) yielded in the presence of the nematode divided by SFM in the absence of it. Reproduction factor $(\mathrm{RF}=\mathrm{Pf} / \mathrm{Pi})$ was calculated using infective nematodes in the root system plus juveniles, immature females and males in soil as the final population (Pf). Infective nematode stages were recorded staining root systems with acid fuchsin (Byrd et al., 1983). Data were submitted to analysis of variance using the SAS GLM procedure and mean separation with Tukey's multiple range test $(P=0.05)$. Reproduction data $(\mathrm{x})$ were transformed to $\log _{10}(\mathrm{x}+1)$ values prior statistical analysis and reported as antlogs.

Although $\mathrm{RB}$ values ranged from 0.32 (C. melo var. inodorus) to 0.64 (C. pepo var. melopepo), there was no difference ( $P>0.05$ ) among genotypes (Figure 1A). In contrast, 


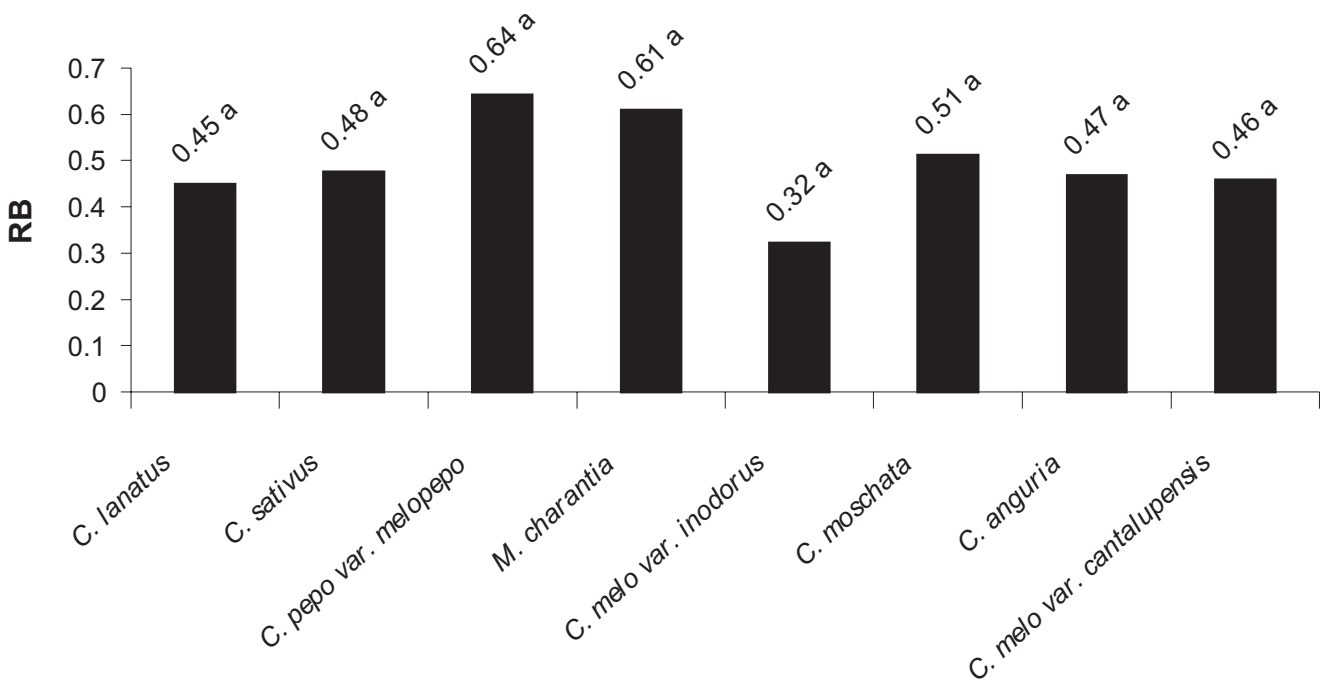

Cucurbit species

B

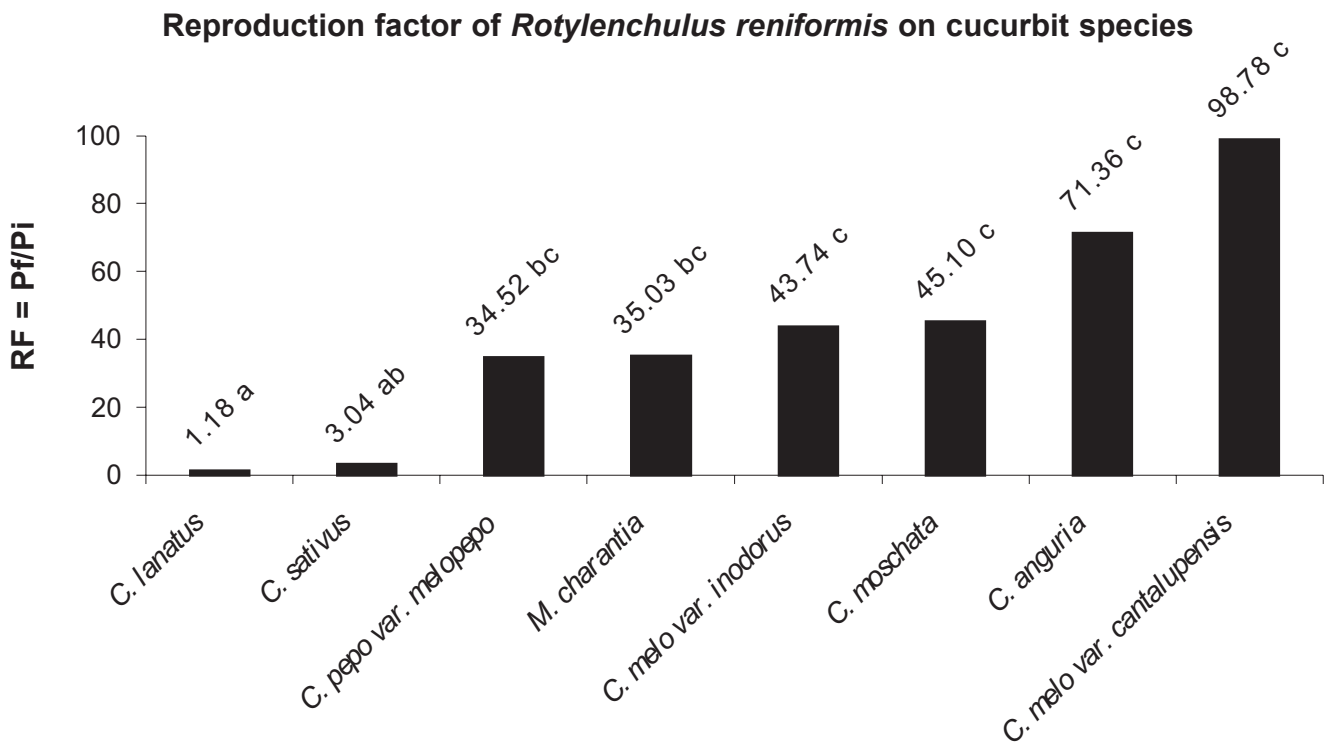

Cucurbit species

FIG. 1 A- Relative biomass (RB = infected plant shoot fresh mass divided by shoot fresh mass of the control) of cucurbit species. B- Rotylenchulus reniformis reproduction factors $(\mathrm{RF}=\mathrm{Pf} / \mathrm{Pi})$ on different cucurbits genotypes. Originals values were transformed to $\log _{10}(\mathrm{x}+1)$ prior to statistical analyses, and antlogs presented. Columns with different letters indicate significant difference based on Tukey multiple range test $(P=0.05)$. $\mathrm{Pf}=$ final population, $\mathrm{Pi}=$ initial population.

RF was affected $(P=0.05)$ by genotype (Figure $1 \mathrm{~B})$. Reproductive factors ranged from 1 to 98 , with C. lanatus $\mathrm{cv}$. Sugar Baby, tending to suppress the nematode reproduction. Due to the high reproduction of $R$. reniformis in C. melo var. inodorus, this genotype is not recommended for infested areas. This fact suggests that after a few cropping seasons the density of nematode may increase to damage levels, therefore inducing high economic losses. This is also true for M. charantia, C. moschata cv. Baiana Tropical, C. pepo var. melopepo cv. Abobrinha Brasileira, C. anguria cv. Maxixe do Norte and C. melo var. cantalupensis (Figure 1B). Momordica charantia, a common weed in melon fields, presented high RF, indicating that this species must be eradicated in melon areas.

In Nematology, resistance has been defined as the effect of the host on nematode reproduction, and tolerance as the absence of yield suppression due to the nematode parasitism (Cook \& Evans, 1987). The search for resistance to $R$. reniformis has been carried out mostly on cotton (Gossypium hirsutum L.) and soybean (Glycine max L.) in 
the United States, and on various legumes in India and Pakistan (Robinson et al., 1997), but these studies are rare in Brazil. According to Boerma \& Hussey (1991), tolerance and resistance are independent qualities of a host plant and the degree of each may vary in different genotypes. The susceptibility of the studied cucurbits suggests that watermelon genotypes should also be tested in future studies.

At the moment, there are no reniform nematoderesistant (or tolerant) melon genotypes available for use in Brazil. However, a watermelon genotype has been found to suppress nematode reproduction, although plant development has also been suppressed. The final population level is critical for management strategies because it may affect crop-rotation sequences. As watermelon is one of the major sources of agricultural income in that state, its introduction in rotation with melon could be useful but is often limited by the lack of alternative crops of equality high-value. Field studies are recommended for more accurate performance of the watermelon Sugar Baby genotype, including yield suppression in highly infested soil.

\section{LITERATURE CITED}

BOERMA, H.R. \& HUSSEY, R.S. Soybean cyst nematode research: resistance and tolerance. Proceedings, $19^{\text {th }}$ Soybean Research Conference, American Soybean Association, Athens, GA. 1991. pp.297-298.

BYRD Jr, D.W., KIRKPATRICK, T. \& BARKER, K.R. An improved technique for clearing and staining plant tissues for detection of nematodes. Journal of Nematology 15:142-143. 1983.

IBGE - Sistema IBGE de recuperação automática - SIDRA. Produção municipal. Disponível em: $<$ http.//www.ibge.gov.br-1k> Acesso em: 26 janeiro 2003.

JENKINS, W.R. A rapid centrifugal-flotation technique for separating nematodes from soil. Plant Disease Reporter 48:692. 1964.

MOURA, R.M., PEDROSA, E.M.R. \& GUIMARÃES, L.M.P. Nematoses de alta importância econômica da cultura do melão no estado do Rio Grande do Norte, Brasil. Fitopatologia Brasileira 27:225. 2002.

ROBINSON, A.F., INSERRA, R.N., CASWELL-CHEN, E.P., VOVLAS, N. \& TROCCOLI, A. Rotylenchulus species: identification, distribution, host ranges, and crop plant resistance. Nematropica 27:127-180. 1997. 